\title{
Correction to: Brief Report: Development and Validation of the Autism Spectrum Knowledge Scale General Population Version: Preliminary Analyses
}

\author{
Maryellen Brunson McClain ${ }^{1} \cdot$ Bryn Harris $^{2} \cdot$ Sarah E. Schwartz ${ }^{1} \cdot$ Kandice J. Benallie $^{1} \cdot$ Megan E. Golson ${ }^{1}$. \\ Chandler M. Benney ${ }^{1}$
}

Published online: 21 December 2021

(c) Springer Science+Business Media, LLC, part of Springer Nature 2021

\section{Correction to: \\ Journal of Autism and Developmental Disorders (2019) 49:3007-3015 \\ https://doi.org/10.1007/s10803-019-04019-8}

Please note the following corrections to this article:
In Table 2 the correct response to Item 12, Some individuals with autism spectrum disorder may be uncoordinated or clumsy, should be True. The corrected Table 2 is shown below.

The original article has been revised.

The original article can be found online at https://doi.org/10.1007/ s10803-019-04019-8.

Maryellen Brunson McClain

maryellen.mcclainverdoes@usu.edu

1 Utah State University, 2810 Old Main Hill, Logan,

UT 84322, USA

2 University of Colorado Denver, Denver, CO, USA 
Table 2 ASKSG Items and Response Choices, with both the percentage of sample responding correctly and estimates of item difficulty from the Rasch Model

\begin{tabular}{|c|c|c|c|c|c|}
\hline \multirow[t]{2}{*}{ Item \# } & \multirow[t]{2}{*}{ Item text } & \multirow[t]{2}{*}{ Correct response } & \multirow[t]{2}{*}{$\begin{array}{l}\text { Observed } \\
\% \text { correct }\end{array}$} & \multicolumn{2}{|c|}{$\begin{array}{l}\text { Item difficulty } \\
\text { parameter } \\
\text { (Eta) }\end{array}$} \\
\hline & & & & Est. & SE \\
\hline 13 & Many individuals with autism spectrum disorder have difficulties expressing themselves & True & 88.68 & -1.494 & 0.178 \\
\hline 10 & Individuals with autism spectrum disorder may have strict routines or rituals & True & 87.42 & -1.368 & 0.170 \\
\hline 5 & Autism spectrum disorder is caused by a lack of motherly warmth & False & 85.85 & -1.225 & 0.162 \\
\hline 11 & Individuals with autism spectrum disorder have difficulties interacting socially or others & True & 83.96 & -1.068 & 0.155 \\
\hline 31 & Many children with autism spectrum disorder are at risk for academic difficulties & True & 83.65 & -1.044 & 0.153 \\
\hline 24 & $\begin{array}{l}\text { Social skills training is an effective treatment for some individuals with autism spec- } \\
\text { trum disorder }\end{array}$ & True & 83.02 & -0.995 & 0.151 \\
\hline 9 & $\begin{array}{l}\text { Children with autism spectrum disorder may not play with toys the way they are } \\
\text { intended }\end{array}$ & True & 81.13 & -0.858 & 0.146 \\
\hline 26 & Most individuals with autism spectrum disorder will never learn to speak & False & 80.50 & -0.815 & 0.144 \\
\hline 17 & If a teacher believes a student has autism spectrum disorder, they can make a diagnosis & False & 79.56 & -0.751 & 0.142 \\
\hline 8 & All individuals with autism spectrum disorder have low intellectual quotients (i.e., IQs) & False & 78.30 & -0.670 & 0.139 \\
\hline 12 & Some individuals with autism spectrum disorder may be uncoordinated or clumsy & True & 75.16 & -0.479 & 0.133 \\
\hline 22 & $\begin{array}{l}\text { There are no beneficial treatments available for individuals with autism spectrum } \\
\text { disorder }\end{array}$ & False & 75.16 & -0.479 & 0.133 \\
\hline 28 & Autism spectrum disorder only affects children & False & 74.84 & -0.460 & 0.133 \\
\hline 27 & Symptoms of autism spectrum disorder do not change throughout an individual's life & False & 71.07 & -0.252 & 0.128 \\
\hline 2 & Vaccines can cause autism spectrum disorder & False & 70.44 & -0.218 & 0.127 \\
\hline 15 & $\begin{array}{l}\text { Diagnosis of autism spectrum disorder is primarily based on behavioral observations } \\
\text { and parent interviews }\end{array}$ & True & 67.92 & -0.089 & 0.124 \\
\hline 30 & $\begin{array}{l}\text { Up to } 70 \% \text { of individuals with autism spectrum disorder also have an additional mental } \\
\text { health diagnosis (e.g., anxiety) }\end{array}$ & True & 66.35 & -0.010 & 0.123 \\
\hline 29 & $\begin{array}{l}\text { Many individuals with autism spectrum disorder have difficulties living and working } \\
\text { independently in adulthood }\end{array}$ & True & 65.09 & 0.051 & 0.122 \\
\hline 3 & Boys are four times as likely than girls to have autism spectrum disorder & True & 64.47 & 0.081 & 0.122 \\
\hline 1 & Less than $2 \%$ of people in the US have autism spectrum disorder & True & 58.81 & 0.346 & 0.119 \\
\hline 25 & $\begin{array}{l}\text { Intellectual quotient (i.e., IQ) and age affect treatment success for children with autism } \\
\text { spectrum disorder }\end{array}$ & True & 58.81 & 0.346 & 0.119 \\
\hline 14 & Symptoms of autism spectrum disorder do not appear before the age of 2 years & False & 56.29 & 0.460 & 0.118 \\
\hline 16 & Autism spectrum disorder can only be diagnosed after the age of 4 years & False & 54.09 & 0.559 & 0.117 \\
\hline 23 & $\begin{array}{l}\text { Restricting certain foods (e.g., gluten) is an effective treatment for autism spectrum } \\
\text { disorder. }\end{array}$ & False & 48.11 & 0.824 & 0.177 \\
\hline 20 & It is possible for autism spectrum disorder to develop into adulthood & False & 42.14 & 1.091 & 0.118 \\
\hline 4 & $\begin{array}{l}\text { Children who have a brother or sister with autism spectrum disorder are more likely to } \\
\text { develop the disorder }\end{array}$ & True & 40.57 & 1.163 & 0.119 \\
\hline 18 & Autism spectrum disorder can be diagnosed with brain imaging & False & 38.68 & 1.249 & 0.120 \\
\hline 19 & $\begin{array}{l}\text { For a diagnosis of autism spectrum disorder, symptoms must be present from early } \\
\text { childhood }\end{array}$ & True & 38.68 & 1.249 & 0.120 \\
\hline 6 & Advanced paternal (father) age is a risk factor for autism spectrum disorder & True & 38.36 & 1.264 & 0.120 \\
\hline 7 & $\begin{array}{l}\text { There are no differences in the identification rates of autism spectrum disorder across } \\
\text { racial and ethnic groups }\end{array}$ & False & 36.16 & 1.367 & 0.121 \\
\hline 21 & A diagnosis of autism spectrum disorder can only be made by a medical doctor & False & 20.44 & 2.222 & 0.142 \\
\hline
\end{tabular}

Publisher's Note Springer Nature remains neutral with regard to jurisdictional claims in published maps and institutional affiliations. 